\title{
Terminologi dan Aspek-aspek Collaborative Problem Solving Skill's
}

\author{
Miksan Ansori \\ Sekolah Tinggi Ilmu Syari’ah Faqih Asy’ari Kediri, Indonesia \\ e-mail: ikhsan.aira@gmail.com
}

\begin{abstract}
Collaborative problem solving is one of a series of abilities that are needed in the 21st century in various aspects of life such as work, community, organization and even in the family. If it is not instilled early on, this ability will not be owned by a person given the flow of globalization and technological development, communication and information in many studies actually gives the effect of exlusivism, individualism and low social attitudes that make it difficult for them to collaborate in solving increasingly complex problems.

Discourse on Collaborative Problem Solving in various aspects is needed. In addition to strengthening and developing science, studies on CPS are needed to further strengthen practitioners to implement them. Before proceeding further in the application and development of Collaborative Problem Solving skills, the meaning and aspects must be clearly known first.
\end{abstract}

Keywords: Collaborative problem solving, Terminology, Skiil's

\section{Pendahuluan}

Banyak kajian mengenai pembelajaran berbasis kolaborasi telah dilakukan oleh para ahli, praktisi serta akademisi. Banyak pula yang membuktikan efektivitasnya dalam meningkatkan nilai akademik maupun penanaman sikap positif peserta didik khususnya dalam aspek sikap inter personal seperti kemampuan saling menghargai, kerja sama, saling ketergantungan yang positif dan banyak lagi. Aspek-aspek positif tersebut tentu saja sangat dibutuhkan dalam bagi peserta didik dalam menjalani kehidupannya apalagi jika melihat perkembangan dan kondisi sosial saat ini yang cenderung sangat individual dan eksklusif. Individu yang sebelumnya menghadapi permasalahan yang lebih sederhana, saat ini harus dipaksa untuk memecahkan masalah yang lebih kompleks yang terkait dalam banyak hal. Kompleksitas permasalahan tersebut sering kali hanya dapat dipecahkan dengan kolaborasi berbagai individu. Jika ditarik resultante, maka perkembangan sosial yang mengarah pada sikap individual dan eksklusif justru kontra produktif jika harus dihadapkan pada permasalahan yang semakin hari semakin kompleks untuk dipecahkan.

Kompetisi yang mengabaikan toleransi diyakini tumbuh sejak individu berada dalam lingkungan sekolah. Proses pembelajaran yang banyak menekankan unsur kompetisi dibandingkan kolaborasi membuat individu lebih sering bersaing dibandingkan bekerja sama. Lebih dari itu, individu juga 'dipaksa' mengalahkan lainnya dibandingkan menolong mereka. Individu yang tidak mampu bersaing akan dimarginalkan sedemikian rupa hingga membuat dirinya kehilangan percaya diri dan semakin tidak berkembang potensinya. Dalam satu titik tertentu, individu yang selalu memenangkan kompetisi jika menghadapi masalah kompleks yang tidak mungkin dipecahkannya sendiri, cenderung akan frustasi karena keengganan berkolaborasi dan memanfaatkan kemampuan di luar dirinya sendiri. Benih-benih egoisme dan individualisme yang tumbuh di lingkungan sekolah haruslah segera di reformasi. Penerapan proses pembelajaran yang menanamkan nilai-nilai kerja sama, saling menghargai dan menghormati, toleransi, menerima perbedaan, hendaknya ditanamkan dan dibiasakan sejak dini. Tanggung jawab semua pihak, seperti pendidik dan peneliti pendidikan, untuk menghadirkan pembelajaran positif bagi peserta didik dengan tidak menafikan tujuan pembelajaran utama. Dalam hal ini, salah satu tugas peneliti adalah menguji efektivitas dan dampak suatu penerapan

Jurnal Dirasah: Volume 1, Nomor 2, Agustus 2018, p-ISSN: 2615-0212, e-ISSN; 26212838

https://ejournal.stisfa-kediri.ac.id/index.php/dirasah 
metode tertentu dalam proses pembelajaran. Sedangkan pendidik diharapkan menerapkan pembelajaran yang mendukung penanaman sikap positif peserta didik.

Dalam banyak kajian, laporan dan penelitian oleh para ahli juga diungkap bahwa pendidikan saat ini belum cukup untuk mempersiapkan siswa dalam menghadapi kebutuhan tantangan kerja, perubahan ekonomi global, perubahan realitas sosial, cepatnya perkembangan teknologi yang melingkupi dunia kerja dan kehidupan serta kebutuhan untuk memberikan kompetensi dan skill prioritas yang harus dimiliki peserta didik di masa yang akan datang

Individu yang mudah bekerja sama dalam memecahkan suatu masalah bisa disebut bahwa dia memiliki collaborrative problem solving skill. Kemampuan CPS tersebut akhir-akhir ini banyak dikaji oleh para ahli dan organisasi-organisasi internasional seperti PISA dan ATC21S. Pembelajaran yang mengembangkan kemampuan Collaborative Problem Solving dapat menjadi jawaban atas fenomena tersebut. Mengingat banyaknya nilai-nilai inter personal dan intra personal yang dapat ditingkatkan dari individu dalam mendukung hubungan sosialnya sekarang maupun di masa yang akan datang. Dua program internasional telah mengembangkan penilaian Collaborative Problem Solving, yaitu ATC21S (Assessment and Teaching of 21st Century Skill) yang didukung oleh Cisco, Intel dan Mikrosoft; serta PISA (Programme for International Student Assessment) yang didukung oleh OECD (Organization for Economic Cooperation and Development). Hal itu membuktikan bahwa Collaborative Problem Solving menjadi isu utama saat ini dalam upaya mengatasi permasalahan pendidikan dan perkembangan zaman bagi peserta didik.

OECD juga menyebutkan bahwa CPS merupakan wilayah penelitian yang relatif baru dan

\footnotetext{
${ }^{1}$ Griffin, P., McGaw, B., \& Care, E. (Eds.) (2012). Assessment and Teaching of 21 st Century Skills. Springer: Dordrecht. OECD (2013). Baca juga Draft PISA Collaborative Problem Solving Framework 2015.

${ }^{2}$ Claire Scoular, Esther Care and Nafisa Awwal, A Generalised Approach to Scoring Students Collaboration in Online: Game Environments. Proceedings of the European Conference on Games Based Learning. Academic Conferences \& Publishing International Ltd. 2016, 584.

${ }^{3}$ Xiaoqing $\mathrm{Gu}$, Shan Chen, Wenbo Zhu, Lin Lin, an Intervention Framework Designed to Develop the Collaborative Problem-
}

banyak menarik peneliti, pendidik, ahli psikologi dan ahli-ahli lainnya. ${ }^{1}$ Ahli psikologi tertarik menjelaskan dan memahami proses CPS, Praktisi pendidikan tertarik untuk menerapkannya, dan peneliti (khususnya dalam bidang pembelajaran) tertarik untuk menguji efektivitas penerapannya. ${ }^{2}$

CPS sebagai sebuah metode pembelajaran terdiri dari dua unsur utama, yaitu collaborative learning dan problem solving. Interaksi sosial dalam collaborrative learning dikombinasikan dengan proses kerja kognitif dan metakognitif individu dalam memecahkan suatu masalah ${ }^{3}$. CPS dapat diterima secara luas oleh para ahli secara luas karena memiliki prinsip bahwa peserta didik harus mengembangkan kemampuan untuk mengkonstruk pemahaman melalui kolaborasi dengan orang lain sehingga peserta didik tersebut akan memahami orang lain dengan baik, serta dia juga akan membangun pengetahuan baru melalui proses pemecahan suatu masalah. ${ }^{4}$

Dalam konteks keilmuan, kajian dan pengembangan kemampuan CPS masih terbatas dan sedikit dilakukan. Misalnya saja Ghu, Chen, Zhu dan Lin mengkaji mengenai CPS melalui kerangka kerja collaborative inquiry project yang menghasilkan hasil positif dan signifikan dalam meningkatkan kemampuan interpersonal dan pemecahan masalah siswa. $^{5}$

\section{Terminologi Cooperative Problem Solving}

CPS terdiri dari dua konsep utama, yaitu collaboration dan problem solving. Dua konsep tersebut telah lama dan banyak dikaji para ilmuan secara parsial serta masing-masing dibahas secara mendalam. Pada level dasar, collaboration dapat dipahami sebagai bekerja sama. Dalam tataran ini, collaboration berarti kondisi kooperatif (menyetujui untuk bekerja bersama-sama, banyak bagian yang berkontribusi), koordinasi sosial (adanya kesadaran

Solving Skills of Primary School Students. (New York: Springer, 2015), 143.

${ }^{4}$ K. Hogan, Thinking Aloud Together: a Test of an Intervention to Foster Students' Collaborative Scientific Reasoning. Journal of Research in Science Teaching, Vol. 36, No. 10 (1999), 10851109. Baca juga M. Scardamalia, C. Bereiter, \& M. Lamon, the CSILE Project: Trying to Bring the Classroom into World 3. In k. Mcgilly (ed.), Classroom Lessons: Integrating Cognitive Theory and Classroom Practice, (pp. 201-228). (Cambridge: MIT Press, 1994), 201-228.

${ }^{5}$ Xiaoqing $\mathrm{Gu}$, an Intervention., 143-159. 
bahwa pihak lain juga dapat berkontribusi yang pada akhirnya membentuk tingkah laku koordinatif). ${ }^{6}$ Tidak hanya itu, kolaborasi juga bermakna suatu pihak bekerja kepada suatu kesatuan untuk mencapai tujuan tertentu yang telah disetujui secara bersama dan sering kali mencocokkan ide-ide untuk membentuk suatu solusi dan keputusan tertentu. ${ }^{7}$

Littleton dan Mercer menyampaikan unsurunsur yang menjadi kata kunci yang merujuk pada konsep kolaborasi, yaitu:

1. melaksanakan koordinasi, yang dilanjutkan dengan usaha untuk memecahkan masalah atau mengkontruks pengetahuan.

2. Berkerja sama dengan komitmen: membagi tujuan, timbal balik, saling menguntungkan dan menelaah makna baru secara berkelanjutan

Dalam bentuk umumnya, yang dimaksud collaborative sebagai unsur pembentuk CPS terdiri collaborative learning (termasuk cooperative learning $^{8}$ ) dan peer tutoring. Dalam CPS, Nesta berpendapat bahwa peer tutoring tidaklah relevan dengan tujuan CPS. Hal itu dikarenakan peer tutoring yang lebih ditujukan pada bagaimana siswa dengan performa tinggi membantu secara akademis siswa yang memiliki performa rendah untuk mereview konsep kritis akademis dan behavioris. ${ }^{10}$ Sedangkan coopertive learning masih sangat relevan dengan tujuan dari CPS. Hal itu dikarenakan dalam konteks cooperative learning kesuksesan individu juga linier dengan kesuksesan kelompok secara keseluruhan dan itu dapat dihasilkan dari tanggung jawab individu, saling ketergantungan positif serta kontribusi nyata

${ }^{6}$ Nesta. Solve! Making the Case for Collaborative Problem Solving (London: SB Victoria Embankment, 2017), 11.

${ }^{7}$ Ibid.

${ }^{8}$ Cooperative learning (CL) berasal dari kata cooperative yang artinya mengerjakan sesuatu secara bersama sama dengan saling membantu satu sama lainnya sebagai satu kelompok atau satu tim. CL memungkinkan dalam sebuah kelompok belajar mampu menampilkan kontribusi setiap individu yang ada di dalamnya untuk meningkatkan kualitas dan mencapai tujuan pembelajaran. Baca R. T. Johnson, \& D. W. Johnson, An Overview of Cooperative Learning. (Baltimore: Brookes Press, 1994).

9 Sebagai sebuah metode pembelajaran peer tutoring dimaksudkan untuk menjembetani kesenjangan usia antara guru dan murid dengan meminta siswa lain yang sudah memahami materi untuk menjadi tutor bagi teman lainnya yang belum memahami sebuah matei pembelajaran. Tidak hanya bermanfaat untuk siswa yang dibimbing, peer tutoring juga diyakini mampu meningkatkan pemahaman pada diri siswa yang menjadi tutor sebayanya. Gordon dalam hal ini menguti ungkapan terkenal dari Canisius (1632) 'He who theaces others, setiap individu. ${ }^{11}$ Kompetensi sosial dan kognitif yang ingin dicapai dalam CPS juga selaras dengan penjelasan cooperative learning yang dikemukakan Slavin, yaitu perspektif sosial, kognitif dan elaborasi kognitif selain perspektif motivasi. ${ }^{12}$

Secara perspektif historis banyak penelitian mengenai collaorative dan cooperative berakar dari dua ahli, yaitu Piaget dan Vigotsky Contohnya adalah socio-constructivis meminjam teori Piaget mengenai tahap perkembangan yang menjelaskan progresifitas kognitif anak, juga ide mengenai konflik kognitif di mana kondisi disonansi pengalaman ketika seseorang menyadari sebuah dicrepancy antara latar kognitif yang ada pada dirinya dengan pengalaman dan informasi baru yang didapatnya. ${ }^{13}$ Sesuai dengan pendekatan sosio-constructivist konflik kognitif merupakan pemicu utama perkembangan kognitif seseorang. Interaksi sosial dengan orang lain membatu seseorang untuk lebih kompleks lagi menghadapi konflik kognitif tersebut sehingga terus berkembang tingkat kognitifnya. ${ }^{14}$ Berdasarkan hal tersebut maka, heterogenitas kelompok sangatlah dibutuhkan agar memiliki pengetahuan yang berbeda, skema representasi pengetahuan yang berbeda, dan perbedaan mekanisme argumentasi. ${ }^{15}$

Sedangkan Vigotsky lebih menekankan pada nilai-nilai interaksi sosial sendiri dalam menyebabkan perubahan kognitif individu, dibandingkan dengan hanya stimulus dari interaksi tesebut. ${ }^{16}$ Dalam pandangannya Vigotsky mengatakan bahwa nilainilai dari interaksi sosial akan diinternalisasi sehingga menyebabkan perubahan konseptual sebagai bentuk

teaches himself,. Baca Edward E. Gordon, Peer Tutoring: A Teacher's Resource Guide (Maryland: R\&L Education, 2005), 1. Baca juga Jennifer Sanders dan RebeccaL. Damron, They're All Writers: Theacing Peer Tutoring in the Elementary Writing Center (New York: Teacers College Pers, 2017). 9.

${ }^{10}$ Nesta. Solve! Making., 10.

${ }^{11}$ O. Korkmaz, A Validity and Reliabilitu Study of the Online Cooperative Learning Attitude Scale (OCLAS). Journal Computers \& Education. Vol. 59. No. 4. 2012. 1162-1169. $\mathrm{http} / / / \mathrm{dx}$.doi.org/10.1016/j.compedu.2012.05.021.

12 R.E. Slavin, Instructional Based on Cooperative Learning. (New York: John Hopkins University Press, 1995), 28.

${ }^{13}$ P. Dillenbourg, M. Baker, A. Blaye, dan C. O'Malley, The evolution of research on collaborative learning. Dalam E. Spada \& P. Reiman (Eds.), Learning in humans and machine: Towards an interdisciplinary learning science (Oxford: Elsevier, 1996) . 189-211.

${ }^{14}$ Ibid.

${ }^{15}$ Emily R. Lai, Collaboration: A Literature Review. Pearson's Research Reports (2011), 8.

${ }^{16}$ P. Dillenbourg, The Evolution., 189-211. 
pemahaman baru. Sama halnya dengan Piaget, Vigotsky berpandangan bahwa perlunya heterogenitas anggota kelompok dalam sebuah bentuk kolaborasi. Hal inti dalam kolaborasi adalah perbedaan capaian ketika dia bekerja sendiri atau saat dia berinteraksi dengan orang lain yang lebih mampu. Dibandingkan harus berfokus pada konflik kognitif, kelompok socio-culture menganggap bahwa collaborative learning lebih dapat memunculkan perkembangan inti kognitif individu. ${ }^{17}$ siswa juga diharuskan mengidentifikasi halanganhalangan yang dihadapi dalam pemecahan masalah, mengevaluasi alternatif-alternatif yang dimiliki dan menyusun tindakan-tindakan yang dibutuhkan dalam mencapai tujuan melalui pemrosesan informasi yang diperolehnya kemudian memilih alternatif-alternatif tersebut untuk dilakukan tidakan yang berorientasi pada tujuan tertentu. ${ }^{19}$ Tentu saja aktivitas-aktivitas problem solving tersebut sangat berkaitan erat dengan kompetensi kognitif siswa. Berbeda dengan

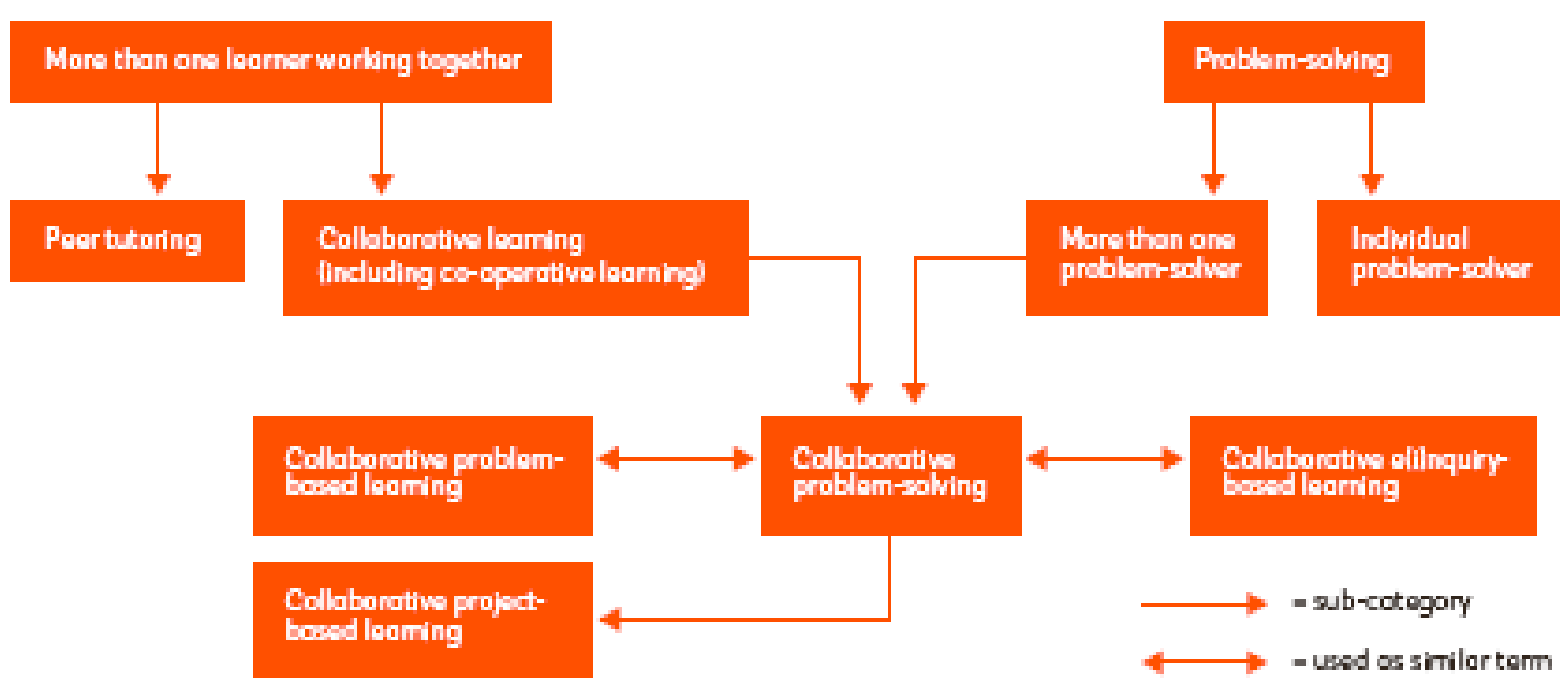

Gambar 1 perpaduan konsep collaborative dan problem solving

Sementara itu, konsep kemampuan problem solving dapat dimaknai sebagai kemampuan individu untuk melakukan proses kognitif untuk memahami dan memecahkan permasalahan tertentu di mana metode pemecahan solusi tidak dapat diketemukan dengan jelas dan cepat. Marzano menjelaskan bahwa proses problem solving terjadi ketika pebelajar berusaha untuk mencapai suatu tujuan yang di dalamnya terdapat rintangan. ${ }^{18}$

Dalam problem solving, seorang siswa juga akan digugah untuk menggunakan pengetahuan relevan yang dimilikinya terhadap sebuah permasalahan dan meretrifikasi pengetahuan sebelumnya. Lebih jauh lagi dalam problem solving,

\footnotetext{
${ }^{17}$ Emily R., Collaboration., 9.

18 Marzano juga mengungkapkan bahwa problem solving merupakan salah satu dari empat proses pemanfaat pengetahuan selain decision-making, Eksperimental Inquiry dan Investigation. Baca R.J. Marzano, Dimension of Thingking: a
}

kompetensi kolaboratif yang dijelaskan sebelumnya, kompetensi kognitif berupa pemecahan masalah (problem soving) tidak berkaitan secara langsung dengan kompetensi interpersonal yang dimilikinya karena sifatnya yang internal. Namun demikian, problem solving sendiri adakalanya dikerjakan seorang diri ada juga yang dikerjakan secara bersamasama. Dalam konteks CPS, problem solving yang dilaksanakan lebih dari satu oranglah yang sesuai dengan tujuan CPS. Permasalahan sendiri muncul ketika seseorang memiliki tujuan tertentu namun dia tidak memiliki solusi yang cepat bagaimana mencapai tujuan tersebut. Mayer mendefinisikan problem solving sebagai proses kognitif yang diarahkan untuk mengubah situasi yang ada ke dalam

Framework of Curriculume and Instruction (Alexandria: The Association for Supervision and Curriculume Development, 1988), 12. Baca juga Helga A. H. Rowe, Problem Soving and intelligence (Hillsdale: Erlbaum, 1985).

${ }^{19}$ Nesta. Solve! Making., 10. 
situasi yang diinginkan ketika tidak adanya sebuah cara yang jelas tersedia. ${ }^{20}$ Oleh karenanya bisa juga dikatakan bahwa proses pemecahan masalah merupakan proses pencarian dan penyediaan sebuah alternatif cara penyelesaian yang jelas dengan tujuan untuk mencapai hasil yang diharapkan. Seperti yang telah dijelaskan sebelumnya, OECD lebih lanjut memaparkan bahwa problem solving sebagai sebuah kompetensi dapat dimaknai sebagai Sementara itu, konsep kemampuan problem solving dapat dimaknai sebagai kemampuan individu untuk melakukan proses kognitif untuk memahami dan memecahkan permasalahan tertentu di mana metode pemecahan solusi tidak dapat diketemukan dengan jelas dan cepat. $^{21}$

Perpaduan dua konsep tersebut (collaborative dan problem solving) secara terminologi membentuk membentuk konsep baru, yakni collaborative problem solving, di mana istilah ini memiliki kesamaan terma dengan collaborative problem based learning atau collaborative inquiry based learning. Ilustrasi yang sesuai mengenai perpaduan konsep collaborative dan problem solving dapat dilihat pada gambar 1. Collaborative problem solving sebagai sebuah konsep tersendiri yang membawa pemecahan masalah yang sifatnya kognitif individual dan proses sosial kolaboratif siswa yang bekerja bersama-sama. Sifat dari sebuah masalah yang dihadapi membutuhkan berbagai sumber daya yang memiliki relevansi untuk dijadikan sebuah resolusi. Berbagai sumber daya tersebut bisa jadi berupa kemampuan dan pengetahuan yang dibawa masing-masing siswa tahu bisa juga berbagai sumber daya yang sifatnya fisik dan praktis ${ }^{22}$.

\section{Collaborative Problem Solving sebagai sebuah kemampuan dan aspek-aspeknya}

Collaborative problem solving merupakan salah satu rangkaian kemampuan yang sangat dibutuhkan pada abad ke $21^{23}$. Rangkaian kemampuan Collaborative problem solving tidak

\footnotetext{
${ }^{20}$ R.E. Mayer, "Problem solving", in Eysenck, M.W. (ed.), The Blackwell Dictionary of Cognitive Psychology, (Blackwell: Oxford Press, 1990), 284.

21 OECD (2010), PISA 2012 Field Trial Problem Solving Framework, http://www.oecd.org/dataoecd/8/42/46962005.pdf ${ }^{22}$ Claire Scoular, Esther Care dan Friedrich W. Hesse Designs for Operationalizing Collaborative Problem Solving for Automated Assessment. Journal of Educational Measurement, Vol. 54, No. 1, (2017). 12-35.
}

terbatas pada satu ranah penelitian saja namun bisa melingkupi banyak konteks seperti pendidikan, kesehatan, kesejahteraan sosial $^{24}$, sumber daya manusia, organisasi serta yang paling baru ditandai dengan adanya proyek AT21CS (Assessment and Teaching of $21^{\text {st }}$ Century Skills) ${ }^{25}$.

Care dan Grivin mengungkapkan bahwa, sebagai sebuah rangkaian kemampuan yang kompleks, CPS memiliki syarat kompetensi sosial dan kognitif. Oleh karenanya, CPS muncul dari keterkaitan antara berpikir kritis (critical thingking), pemecahan masalah (problem solving), penentuan keputusan (decision making) dan kolaborasi (collaboration); di mana semua proses diasumsikan berkontribusi terhadap kemampuan CPS. Sebelumnya O'Neil mendefinisikan problem solving sebagai persyaratan terhadap pemahaman isi, strategi pemecahan masalah, dan runtutan proses dan progres pemecahan masalah seseorang.

Hesse, Care, Sassenberg, Buder, and Griffin memberikan konsep bahwa CPS merupakan struktur yang mencakup lima hal, yaitu partisipasi, memahami sudut pandang orang lain, aturan sosial dan aturan tugas serta konstruksi pengetahuan. Kelima hal tersebut dapait dikelompokkan menjadi dua hal yaitu kognitif dan sosial. Para ahli mengartikan CPS sebagai serangkaian kemampuan yang individu butuhkan ketika kapasitas atau sumber daya satu orang saja tidak mencukupi untuk memecahkan suatu masalah. Serangkaian kemampuan tersebut kemudian mampu mengkombinasikan perbedaan sumber daya dan kemampuan ketika dihadapkan pada permasalahan yang kompleks.

Hesse dkk. tampak tidak berseberangan dengan O'Neill dalam mendefinisikan CPS. Kedua menekankan unsur sosial dan kognitif. Namun Hesse dkk. tampak lebih memberikan penekanan pada aspek sosial dibandingkan dengan unsur kognitif individu. Aturan sosial termasuk di dalamnya adalah mengerahkan segenap kemampuan untuk mengelola ruang interpersonal dengan tujuan untuk berinteraksi

\footnotetext{
${ }^{23}$ Esther Care Patrick Griffin, an Approach to Assessment of Collaborative Problem Solving. Research and Practice in Technology Enhanced Learning Journal. Vol. 9, No. 3 (2014). Asia-Pacific Society for Computers in Education. 370.

24 A. Pollastri, L. Epstein, G. Heath, \& S. Ablon, the Collaborative Problem Solving Approach: Outcomes Across Settings. Harvard Review of Psychiatry, Vol. 21, No. 4 (2013), 188-199.

${ }^{25}$ P. Griffin, Assessment and Teaching., 9.
} 
dalam memecahkan suatu masalah tertentu. Sedangkan aturan tugas lebih dimaksudkan sebagai kemampuan-kemampuan yang digunakan dalam memetakan ruang masalah dalam perspektif dirinya sendiri. Sering kali pertanyaan yang muncul adalah sumber daya, artifisial dan proses yang mungkin diikuti.

Dalam memberikan definisi kemampuan CPS, PISA merevisi beberapa definisi yang telah diungkapkan, hal itu dapat dipahami mengingat berkembangnya pula kajian dan objek penelaahan kemampuan CPS. Definisi kemampuan CPS pada tahun 2015 (merupakan revisi dari definisi yang dikeluarkan tahun 2003 dan 2012) menurut PISA, yaitu kapasitas seorang individu yang secara efektif terlibat dalam proses di mana dua atau lebih pihak berusaha untuk memecahkan suatu masalah melalui berbagi pemahaman dan melakukan usaha yang dibutuhkan untuk menghadirkan solusi dengan memadukan pengetahuan, kemampuan dan tindakan untuk mencapai solusi tersebut. ${ }^{26}$

Kemampuan berkolaborasi sebenarnya tidak hanya ada pada level individu, namun dapat pula pada tingkatan kelompok atau organisasi ${ }^{27}$. Hasil utama dari berkolaborasi adalah terpecahkannya suatu masalah dengan hasil yang lebih baik dibandingkan jika masalah tersebut ditangani satu orang saja ${ }^{28}$. Selain itu, dalam tingkatan individu tentu tidak cukup menggambarkan bagaimana suatu kelompok secara keseluruhan menghasilkan hasil yang berbade jika dibandingkan jika suatu masalah tersebut diselesaikan sendiri. Efektivitas dari CPS sendiri sangat tergantung dari anggota kelompok dalam bekerja sama dan mengutamakan kesuksesan bersama dibandingkan kesuksesan individu. Dalam konteks ini, tentu kemampuan CPS sangatlah menunjang kehidupan saat ini maupun yang akan datang, mengingat pluralisme masyarakat semakin kental tidak hanya dalam lingkung bangsa dengan kebhinekaannya saja, namun kebhinekaan tersebut telah terkoneksi sedemikian rupa sehingga masingmasing telah berada dalam kehidupan bersama yang

\footnotetext{
${ }^{26}$ Draft PISA Collaborative Problem Solving Framework 2015

${ }^{27}$ Campbell, J., "Individual versus Group Problem Solving in an Industrial Sample", Journal of Applied Psychology, Vol. 52 (1968), 205-210. Baca juga G. Stahl, Group Cognition: Computer Support for Building Collaborative Knowledge, (Cambridge: MIT Press, 2006).
}

lebih dekat lagi. Tentu dalam menjalani kehidupan sosial bersama tersebut akan dijumpai tantangan dan permasalahan yang harus dicarikan solusinya. Kemampuan individu untuk berkolaborasi dan mengutamakan kepentingan dan kesuksesan bersama sangatlah dibutuhkan di tengah banyaknya pola-pola kehidupan eksklusif, individualis dan egois.

Seperti yang telah dijelaskan pada sub bab sebelumnya bahwa CPS terkait dengan proses kognitif yang ada pada individu yang melibatkan kemampuan kognitif dan sosial. Terdapat proses pemecahan masalah dalam tingkat individu juga interaksi komunikatif dengan sistem kognitif dari individu lain yang juga mengalami proses yang sama dalam lingkup kolaborasi. Misalnya saja sebuah kelompok tidak hanya memiliki solusi yang benar, namun kelompok tersebut harus pula menyetujui solusi tersebut secara bersama-sama. Titik tengah persetujuan tersebut bisa disebut resultan (resultante) di antara kebenaran-kebenaran subjektif yang dihadirkan masing-masing pihak dalam kelompok sehingga ditarik sebuah kesepakatan bersama dalam memecahkan suatu permasalahan. Titik kesepakatan yang dicapai dari interaksi bersama dan persilangan sistem kognitif masing-masing pihak ada kalanya tidak dicapai dengan mudah dikarenakan kompleksnya suatu masalah atau belum adanya persetujuan dari seluruh pihak dalam kelompok kolaborasi karena beberapa hal seperti adanya kepentingan, cara berkomunikasi dan lain sebagainya. Dalam kondisi tersebut kemampuan CPS sangatlah dibutuhkan untuk menunjang keberhasilan kolaborasi seperti bagaimana membagi pemahaman, melakukan tindakan yang paling sesuai dalam pemecahan suatu masalah dan tetap menjaga keutuhan dalam bingkai kolaboratif yang ideal.

Proses kognitif individu dalam CPS merupakan peristiwa internal dalam diri individu, namun proses tersebut termanifestasikan dalam interaksi individu tersebut dengan permasalahan yang dihadapi untuk dipecahkan dan individu atau pihak lain yang ada dalam proses kolaborasi. Proses

28 D. L. Schwartz, "the Emergence of Abstract Dyad Representations in Dyad Problem Solving", The Journal of the Learning Sciences, Vol. 4, (1995), 321-354. Baca juga E. Aronson, dan S. Patnoe, The jigsaw classroom: Building cooperation in the classroom (2nd ed.) (New York: Longman,1997). 
kognitif (internal maupun persinggungan dengan masalah atau individu lain) selanjutnya dapat disimpulkan dari tindakan-tindakan yang ditampilkan oleh seseorang, komunikasi yang dilakukan dengan orang lain, hasil sementara dan hasil akhir dari tugastugas dalam rangka refleksi dan representasi pemecahan masalah.

Kolaborasi yang mensyaratkan setidaknya dua pihak atau lebih sebagai syarat sebuah kolaborasi. Pihak yang dimaksud bisa seseorang ataupun sekelompok orang, bisa juga seseorang yang terkoneksi dalam dunia maya. Pihak-pihak yang terlibat hendaknya mampu mengarah pada tujuan, menampilkan sebuah tindakan, mengkomunikasikan pesan, memberikan reaksi terhadap pesan yang disampaikan pihak lain; merasakan, beradaptasi dan belajar dari lingkungan yang ada.

Definisi PISA yang telah disebutkan di atas sebelumnya berangkat dari tujuan untuk program penilaian kemampuan CPS PISA 2015. Pada definisi kolaborasi tersebut dapat diketahui tiga kompetensi utama, yaitu:

1. Membangun dan memelihara pemahaman bersama

Jika diarahkan dalam konteks pendidikan, maka kemampuan tersebut dapat dimaknai bahwa siswa harus memiliki kemampuan untuk mengidentifikasi apakah masing-masing telah mengetahui dan memahami masalah yang dihadapi bersama tersebut. Selain itu, juga siswa harus mampu mengidentifikasi sudut pandang masing-masing pihak dalam memahami masalah serta membangun visi bersama dalam menentukan permasalahan dan aktivitas. ${ }^{29} \mathrm{Hal}$ ini juga termasuk dalam kemampuan siswa dalam menilai bagaimana kemampuan, pengetahuan dan sudut pandangnya terhadap permasalahan yang dihadapi dalam berinteraksi

\footnotetext{
29 J.A. Cannon-Bowers, and E. Salas, "Reflections on shared cognition", Journal of Organisational Behavior, Vol. 22 (2001), 195-202. Baca juga S. M. Fiore, and J.W. Schooler, "Process mapping and shared cognition: Teamwork and the development of shared problem models", in Salas, E. and S.M. Fiore (eds.), Team cognition: Understanding the factors that drive process and performance (Washington DC: American Psychological Association, 2004), 133-152.

30 H. H. Clark, and S.E. Brennan, "Grounding in Communication", dalam L. B. Resnick, J.M. Levine and S.D. Teasley (eds.), Perspectives on Socially Shared Cognition (Washington DC: American Psychological Association, 1991),
}

dengan pihak lain saat dia berada dalam proses kolaborasi atau berhubungan dengan orang lain. Banyak teori-teori yang telah disampaikan para ahli tentang pentingnya membangun persamaan persepsi agar komunikasi yang baik berhasil dicapai. ${ }^{30}$

2. Mengambil tindakan yang sesuai dalam pemecahan masalah

Seseorang harus mampu mengidentifikasi jenisjenis aktivitas CPS yang dibutuhkan dan mengikuti langkah-langkah yang sesuai dalam penyelesaian masalah. Hal ini termasuk usahausaha untuk memahami masalah yang dihadapi, menciptakan tujuan kelompok untuk menemukan solusi, mengambil tindakan, dan mengawasi hasil-hasil pencapaian dalam kerja sama dalam kelompok tersebut dan juga hasil pemecahan masalah yang dihadapi. Dalam rangkaian tindakan terbut, bisa jadi berisikan tindakan berkomunikasi seperti menjelaskan, negosiasi, perdebatan dan argumentasi dalam rangka membentuk solusi yang lebih kreatif dan optimal untuk dicapai melalui kompleksitas informasi dan sudut pandang yang dimiliki masing-masing pihak dalam kelompok kolaborasi. Dalam konteks pembelajaran, tindakan-tindakan tersebut dapat dijumpai dalam langkah-langkah strategi pembelajaran yang sesuai dengan aktivitas CPS seperti jigsaw problem $^{31}$, collaborative work $^{32}$, debat argumentasi dalam penentuan keputusan ${ }^{33}$ dan lain sebagainya.

Membangun dan memelihara pemahaman kelompok

Kelompok kolaborasi tidak akan berfungsi secara efektif tanpa adanya pengorganisasian kelompok dan pemahaman tugas-tugas dalam pemecahan masalah. Seseorang harus mampu

127-149. Baca juga H.H. Clark, Using language, (Cambridge: Cambridge University Press, 1996).

${ }^{31}$ E. Aronson, dan S. Patnoe, the Jigsaw Classroom: Building Cooperation in the Classroom, (New York: Longman, 1997), 8.

${ }^{32}$ Y. Rosen, and R. Rimor, "Using Collaborative Database to Enhance Students' Knowledge Construction", Interdisciplinary Journal of E-Learning and Learning Objects, Vol. 5, (2009), 187-195.

${ }^{33}$ C.O. Stewart, , L. D. Setlock and S. R. Fussell, "Conversational Argumentation in Decision-Making: Chinese and U.S. Participants in Face-to-Face and Instant-Messaging Interactions", Discourse Processes, Vol. 44, (2007), 113-139. 
memahami tugas-tugasnya sendiri dalam kelompok tersebut, serta tugas-tugas pihak lain berdasarkan pengetahuan dan kemampuan masing-masing (transactive memory), mengikuti aturan-aturan yang telah disepakati bersama saat melaksanakan tugas-tugas yang diberikan, mengawasi organisasi kelompok, memfasilitasi perbedaan kebutuhan untuk mengatasi masalah komunikasi, dan rintangan-rintangan dalam pencapaian tujuan.

Tiga kompetensi tersebut lahir dari paduan kolaborasi dan proses pemecahan masalah yang ada dalam internal individu. Proses pemecahan masalah sendiri, sesuai dengan rumusan PISA 2012 telah dijabarkan terdiri dari: mengeksplorasi dan memahami, merepresentasi dan memformulasi, merencanakan dan mengeksekusi, mengawasi dan merefleksi.

Selanjutnya, PISA 2015 memadukan tiga kompetensi utama kolaborasi dengan empat kompetensi utama proses problem solving, dan membentuk matriks gabungan kemampuan keduanya atau Matrix of collaborative problem solving yang dapat dilihat pada tabel 1 .

Tabel 1 Matrix of collaborative problem solving

\begin{tabular}{|c|c|c|c|}
\hline & $\begin{array}{l}\text { (1) Establishing and } \\
\text { maintaining shared } \\
\text { understanding }\end{array}$ & $\begin{array}{l}\text { (2) Taking } \\
\text { appropriate action } \\
\text { to solve the } \\
\text { problem }\end{array}$ & $\begin{array}{l}\text { (3) Establishing and } \\
\text { maintaining team } \\
\text { organisation }\end{array}$ \\
\hline $\begin{array}{l}\text { (A) Exploring and } \\
\text { understanding }\end{array}$ & $\begin{array}{l}\text { (A1) Discovering } \\
\text { perspectives and abilities } \\
\text { of team members }\end{array}$ & $\begin{array}{l}\text { (A2) Discovering } \\
\text { the type of } \\
\text { collaborative } \\
\text { interaction to solve } \\
\text { the problem, along } \\
\text { with goals }\end{array}$ & $\begin{array}{l}\text { (A3) Understanding roles } \\
\text { to solve the problem }\end{array}$ \\
\hline $\begin{array}{l}\text { (B) Representing } \\
\text { and formulating }\end{array}$ & $\begin{array}{l}\text { (B1) Building a shared } \\
\text { representation and } \\
\text { negotiating the meaning } \\
\text { of the problem (common } \\
\text { ground) }\end{array}$ & $\begin{array}{l}\text { (B2) Identifying } \\
\text { and describing } \\
\text { tasks to be } \\
\text { completed }\end{array}$ & $\begin{array}{l}\text { (B3) Describe roles and } \\
\text { team organisation } \\
\text { (communication } \\
\text { protocol/rules of } \\
\text { engagement) }\end{array}$ \\
\hline $\begin{array}{l}\text { (C) Planning and } \\
\text { executing }\end{array}$ & $\begin{array}{l}\text { (C1) Communicating } \\
\text { with team members } \\
\text { about the actions to } \\
\text { be/being performed }\end{array}$ & (C2) Enacting plans & $\begin{array}{l}\text { (C3) Following rules of } \\
\text { engagement, (e.g. } \\
\text { prompting other team } \\
\text { members to perform their } \\
\text { tasks) }\end{array}$ \\
\hline $\begin{array}{l}\text { (D) Monitoring and } \\
\text { reflecting }\end{array}$ & $\begin{array}{l}\text { (D1) Monitoring and } \\
\text { repairing the shared } \\
\text { understanding }\end{array}$ & $\begin{array}{l}\text { (D2) Monitoring } \\
\text { results of actions } \\
\text { and evaluating } \\
\text { success in solving } \\
\text { the problem }\end{array}$ & $\begin{array}{l}\text { (D3) Monitoring, } \\
\text { providing feedback and } \\
\text { adapting the team } \\
\text { organisation and roles }\end{array}$ \\
\hline
\end{tabular}

\section{Penutup}

Kemampuan Collaborative Problem Solving pada saat ini dan masa yang akan datang akan sangat dibutuhkan individu dalam berbagai aspek kehidupannya seperti dalam pekerjaan, bermasyarakat, berorganisasi dan bahkan dalam keluarga. Jika tidak ditanamkan sejak dini, kemampuan ini tidak akan dimiliki seseorang mengingat arus globalisasi dan perkembangan teknologi,komunikasi dan informasi dalam banyak kajian justru memberikan efek ekslusivisme, individualisme dan rendahnya sikap sosial sehingga membuat mereka kesulitan berkolaborasi dalam menyelesaikan masalah yang semakin kompleks.

Diskursus mengenai Collaborative Problem Solving dalam berbagai aspek sangat dibutuhkan. Selain sebagai penguatan dan pengembangan 
keilmuan, kajian mengenai CPS diperlukan untuk semakin memantapkan para praktisi untuk menerapkannya. Sebelum melangkah lebih jauh dalam pengaplikasian dan pengembangan kemampuan Collaborative Problem Solving, hendaknya makna dan aspek-aspeknya harus diketahui secara jelas terlebih dahulu.

Berdasarkan uraian yang telah dipaparkan di atas, dapat diketahui bahwa Collaborative Problem Solving adalah kapasitas seorang individu yang secara efektif terlibat dalam proses di mana dua atau lebih pihak berusaha untuk memecahkan suatu masalah melalui berbagi pemahaman dan melakukan usaha yang dibutuhkan untuk menghadirkan solusi dengan memadukan pengetahuan, kemampuan dan tindakan untuk mencapai solusi tersebut.

Sedangkan kemampuan Collaborative Problem Solving dapat dijelaskan lebih rinci dengan memadukan kemampuan kolaborasi (membangun dan memelihara pemahaman bersama, mengambil tindakan yang sesuai dalam pemecahan masalah dan membangun dan memelihara pemahaman kelompok) dan aspek-aspek problem solving) dan aspek-aspek problem solving (mengeksplorasi dan memahami, merepresentasi dan memformulasi, merencanakan dan mengeksekusi, mengawasi dan merefleksi).

\section{Daftar Pustaka}

Aronson, E. dan Patnoe,S. The jigsaw classroom: Building cooperation in the classroom (2nd ed.). New York: Longman. 1997.

C.O. Stewart, , L. D. Setlock and S. R. Fussell, "Conversational Argumentation in DecisionMaking: Chinese and U.S. Participants in Faceto-Face and Instant-Messaging Interactions", Discourse Processes, Vol. 44, (2007), 113-139.

Campbell, J., "Individual versus Group Problem Solving in an Industrial Sample", Journal of Applied Psychology, Vol. 52 (1968), 205-210.

Cannon-Bowers, J.A. and Salas, E. "Reflections on shared cognition". Journal of Organisational Behavior. Vol. 22 (2001).

Care, Esther. Griffin, Patrick. an Approach to Assessment of Collaborative Problem Solving. Research and Practice in Technology Enhanced Learning Journal. Vol. 9, No. 3 (2014).
Clark, H. H. and Brennan, S.E. "Grounding in Communication", dalam L. B. Resnick, J.M. Levine and S.D. Teasley (eds.), Perspectives on Socially Shared Cognition. Washington DC: American Psychological Association. 1991.

Clark, H.H. Using language. Cambridge: Cambridge University Press. 1996.

Dillenbourg, P. Baker, M. Blaye, A. dan O’Malley, C. the Evolution of Research on Collaborative Learning. Dalam E. Spada \& P. Reiman (Eds.), Learning in Humans and Machine: Towards an Interdisciplinary Learning Science. Oxford: Elsevier. 1996. 189-211.

Draft PISA Collaborative Problem Solving Framework 2015

Fiore, S. M. and Schooler, J.W. "Process mapping and shared cognition: Teamwork and the development of shared problem models". in Salas, E. and S.M. Fiore (eds.). Team cognition: Understanding the factors that drive process and performance. Washington DC: American Psychological Association. 2004.

Gordon, Edward E. Peer Tutoring: A Teacher's Resource Guide. Maryland: R\&L Education. 2005.

Griffin, P., McGaw, B., \& Care, E. (Eds.) (2012). Assessment and Teaching of 21st Century Skills. Springer: Dordrecht. OECD (2013).

Gu, Xiaoqing. Chen, Shan. Zhu, Wenbo. dan Lin, Lin. an Intervention Framework Designed to Develop the Collaborative Problem-Solving Skills of Primary School Students. New York: Springer. 2015.

Hogan, K. Thinking Aloud Together: a Test of an Intervention to Foster Students' Collaborative Scientific Reasoning. Journal of Research in Science Teaching. Vol. 36. No. 10 (1999). 1085-1109.

Johnson, R. T. \& Johnson, D. W. An Overview of Cooperative Learning. Baltimore: Brookes Press. 1994.

Korkmaz, O. A Validity and Reliabilitu Study of the Online Cooperative Learning Attitude Scale (OCLAS). Journal Computers \& Education. Vol. 59. No. 4. 2012. 1162-1169. 
http://dx.doi.org/10.1016/j.compedu.2012.05.0 21.

Lai, Emily R. Collaboration: A Literature Review. Pearson's Research Reports. 2011.

Marzano, R.J. Dimension of Thingking: a Framework of Curriculume and Instruction. Alexandria: The Association for Supervision and Curriculume Development. 1988.

Mayer, R.E. "Problem solving", in Eysenck, M.W. (ed.), The Blackwell Dictionary of Cognitive Psychology. Blackwell: Oxford Press. 1990.

Nesta. Solve! Making the Case for Collaborative Problem Solving. London: SB Victoria Embankment. 2017.

OECD (2010), PISA 2012 Field Trial Problem Solving Framework, http://www.oecd.org/dataoecd/8/42/46962005. pdf

Pollastri, A. Epstein, L. Heath, G. \& Ablon, S. the Collaborative Problem Solving Approach: Outcomes Across Settings. Harvard Review of Psychiatry, Vol. 21, No. 4 (2013), 188-199.

Rosen, Y. and Rimor, R. "Using Collaborative Database to Enhance Students' Knowledge Construction". Interdisciplinary Journal of ELearning and Learning Objects. Vol. 5. (2009). 187-195.

Rowe, Helga A. H. Problem Soving and intelligence. Hillsdale: Erlbaum, 1985.
Sanders, Jennifer. dan Damron, Rebecca L. They're All Writers: Theacing Peer Tutoring in the Elementary Writing Center. New York: Teacers College Perss. 2017.

Scardamalia, M. Bereiter, C. \& Lamon, M. the CSILE Project: Trying to Bring the Classroom into World 3. In k. Mcgilly (ed.). Classroom Lessons: Integrating Cognitive Theory and Classroom Practice. Cambridge: MIT Press. 1994. 201-228.

Schwartz, D. L. "the Emergence of Abstract Dyad Representations in Dyad Problem Solving". The Journal of the Learning Sciences. Vol. 4. (1995). 321-354.

Scoular, Claire. Care Esther dan Hesse, Friedrich W. Designs for Operationalizing Collaborative Problem Solving for Automated Assessment. Journal of Educational Measurement, Vol. 54, No. 1, (2017). 12-35.

Scoular, Claire. Care Esther, and Awwal, Nafisa. A Generalised Approach to Scoring Students Collaboration in Online: Game Environments. Proceedings of the European Conference on Games Based Learning. Academic Conferences \& Publishing International Ltd. 2016, 584.

Slavin, R.E. Instructional Based on Cooperative Learning. New York: John Hopkins University Press. 1995.

Stahl, G. Group Cognition: Computer Support for Building Collaborative Knowledge. Cambridge: MIT Press. 2006.

Copyright (C) 2018 Journal Dirasah: Vol. 1, No. 2, August 2018, p-ISSN: 2615-0212, e-ISSN; 26212838

Copyright rests with the authors

Copyright of Jurnal Dirasah is the property of Jurnal Dirasah and its content may not be copied or emailed to multiple sites or posted to a listserv without the copyright holder's express written permission. However, users may print, download, or email articles for individual use. https://ejournal.stisfa-kediri.ac.id/index.php/dirasah 